\title{
$\mathrm{Si}$ 単結晶マイクロエレメントの破壊・疲労特性評価と水環境効果*
}

\author{
駒 井 謙治郎*1 箕 島 弘 二*1 \\ 井上茂 道*2 藤 井秀 敏*2
}

\section{Evaluation of Fracture and Fatigue Strength of Single-Crystal Silicon Microelements and Influence of Water}

\author{
Kenjiro KOMAI, Kohji MINOSHIMA. \\ Shigemichi INOUE and Hidetoshi FUJII
}

\begin{abstract}
Quasi static and fatigue tests of single crystal silicon microelements fabricated by micromachining (photoetching) were performed. The cantilever beam microelements were subjected to simple bending using a specially designed testing machine. Extremely small loads could be applied to a microelement by means of an electromagnetic actuator, and quasi static and fatigue tests could thereby be performed with sufficient precision. Silicon microelements deformed elastically until final catastrophic failure, giving a brittle nature. The fracture strengths increased with decreasing specimen size. Fatigue tests were performed, and the influence of water on fatigue strength was discussed. The fracture surface and sample surface were examined in detail using a scanning clectron microscope (SEM) and an atomic force microscope (AFM), and the fracture mechanisms were discussed
\end{abstract}

Key Words: Fracture, Fatigue, Environmental Effects, Fracture Strength, Testing Machine, Microelement, Single Crystal silicon, Photoetching, Size Effect. Fractography, Atomic Force Microscopy, Micromachine

\section{1. 緒 镸}

微紏加に:技術を結集したくイクロマシン0卢現は，

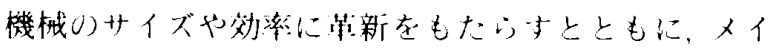

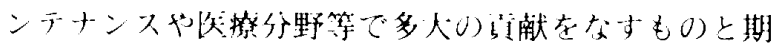

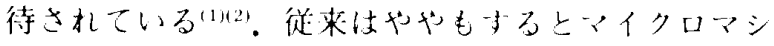

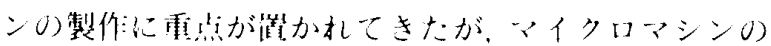

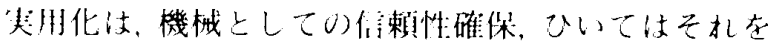

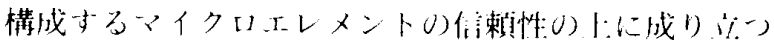

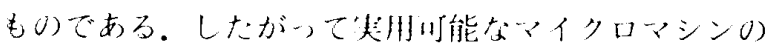
央現にあたって注、マイクロッシンを構成する微小機

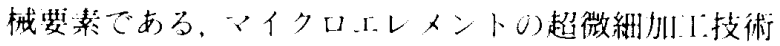

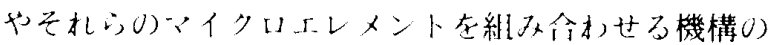
開発とともに、アイクロエレメントの機械的性驾，波

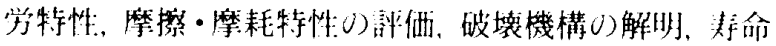

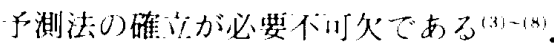

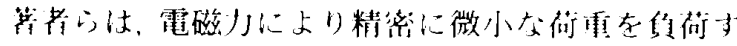

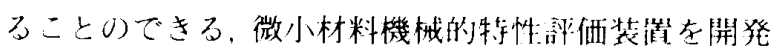

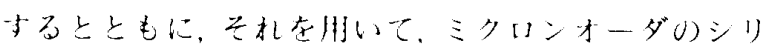

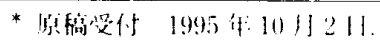

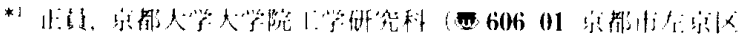

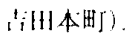

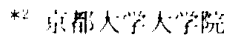

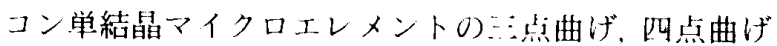
試験を用い，その静的機械的特性に及位異方性エッ チングやダイシングかいなどの加法や試験け・サイズ

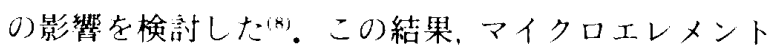

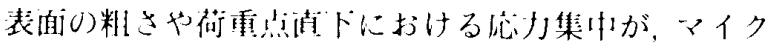
ロエレメントの機械的特性に大きな影響を寺えること が明らかとなった(メ)。るこで，本研究に扔いては，衔重

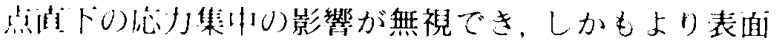

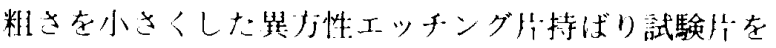
用いて、静的曲げ゙武験を行った。併せて，変動仙力下の

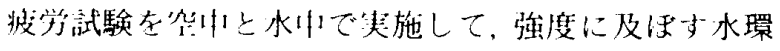

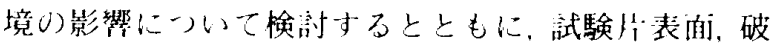

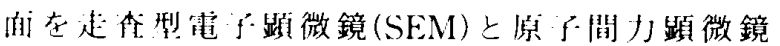
(AFM)を肺いて詳紐に観察して,シリコン単結晶マ イクロエレメントリ破壊機構について検討を加えた。

\section{2. 実 験 方 法}

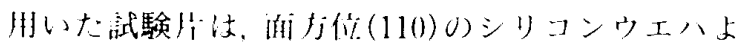

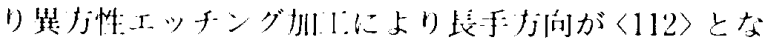
るように作娍した：点朋げ試験片（断的形状：台形、

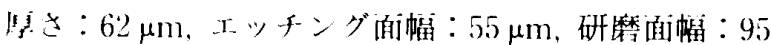

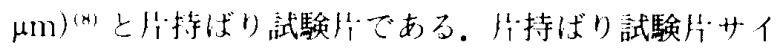

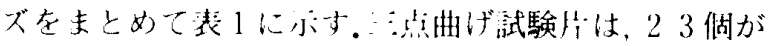




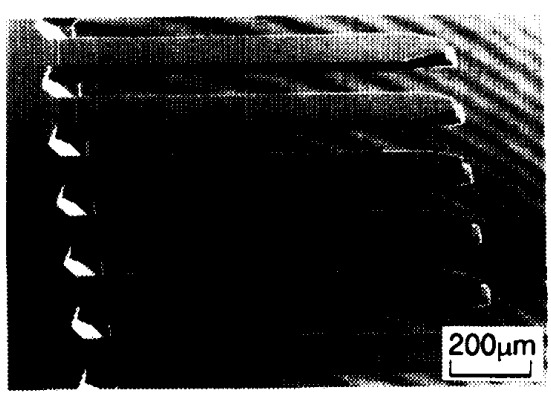

(a) General view

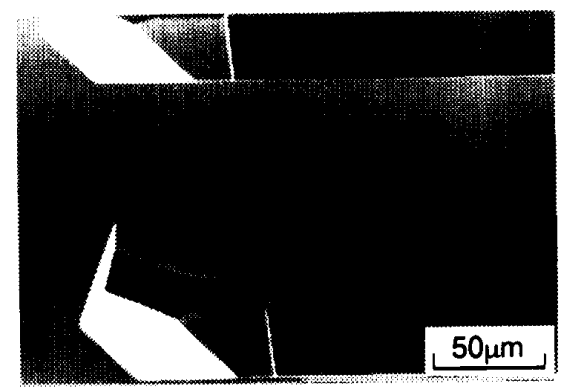

(b) Polished surface

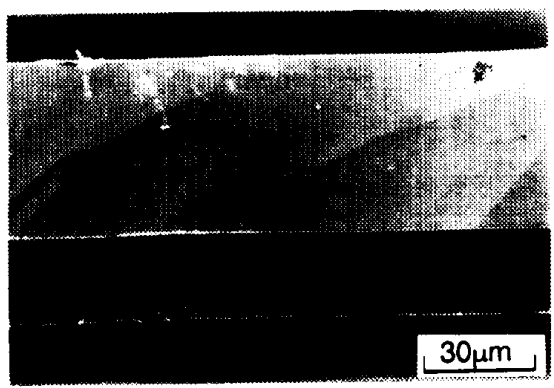

(c) Etched surface

Fig. 1 SE.M Photographs of microcantilever beam specimens

Table 1 Dimensions of cantilever beam specimens

\begin{tabular}{ccc} 
Width $w(\mu \mathrm{m})$ & Thickness $\mathrm{t}(\mu \mathrm{m})$ & Length $(\mu \mathrm{m})$ \\
\hline 195 & 30 & 2000 \\
145 & 30 & 1500 \\
95 & 30 & 1000 \\
65 & 30 & 1000 \\
45 & 30 & 500
\end{tabular}

" $w$ " and " $\mathrm{t}$ " are defined in Fig. 2

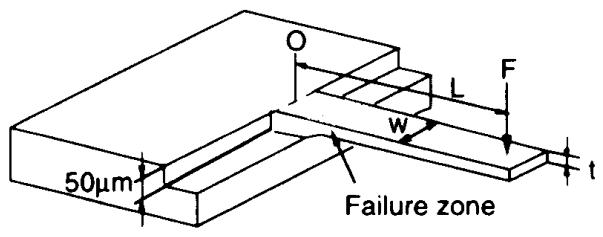

Fig. 2 Schematics of a microcantilever beam specimen

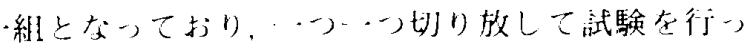

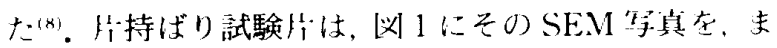
た，洞2に模式应を亦すように、シリコンウエハにに 列に业んで作成されている。試験の際は，负れらの 試験片をウエハごと比り出し、アルミニウム製ブロッ クに接着しそそのブロックを試験機に固定した。兰恕 曲げ試験片と闹樣に，試験片け面は研磿面であり，側

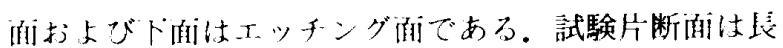

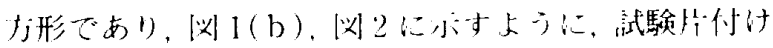

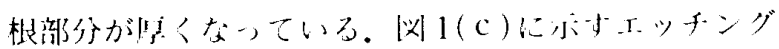
面は，研糜面と比較すると粗さは大きい.AFM在㖄い

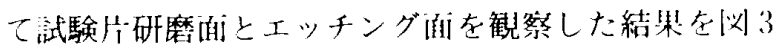

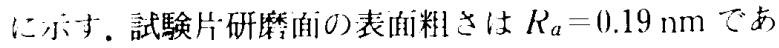

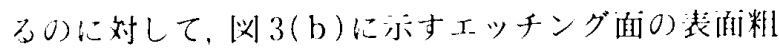

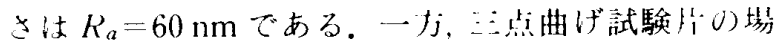

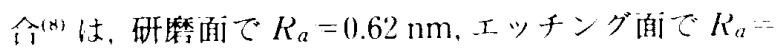

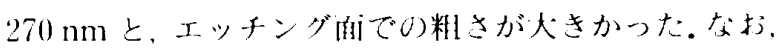

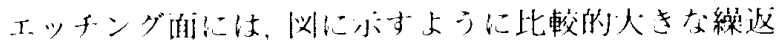

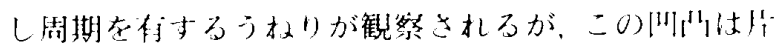

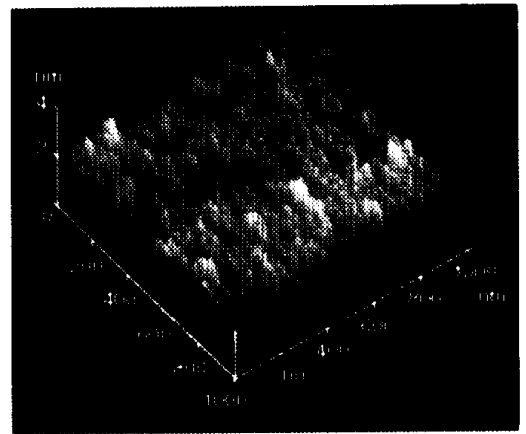

(a) Polished surface

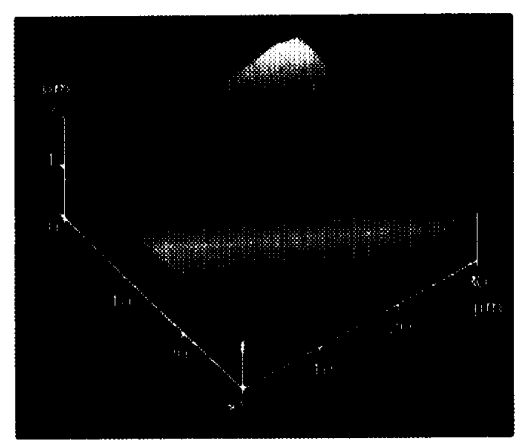

(b) Etched surface

Fig. 3 AFM topography of a microcantilever beam specimen

持ばり試験片の場令で約 $200300 \mathrm{~nm}$ 程度であった。

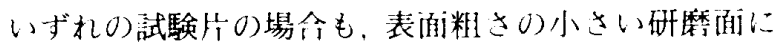

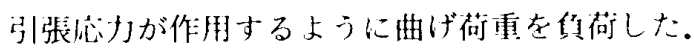

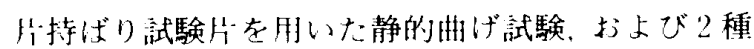

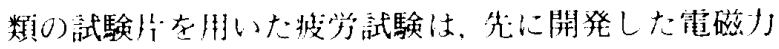

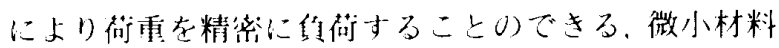

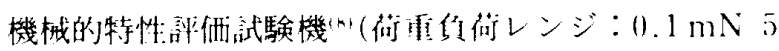

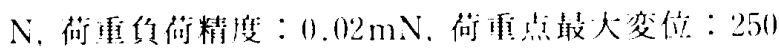

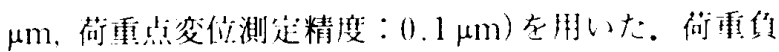

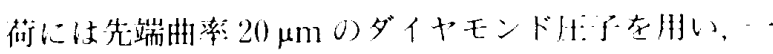

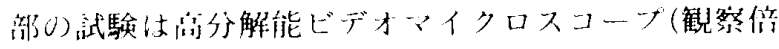

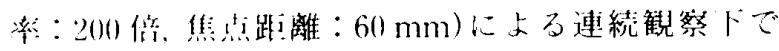

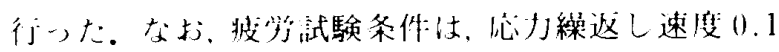

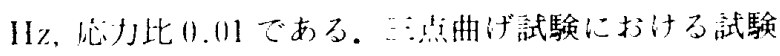


片支持には直径 $0.6 \mathrm{~mm}$ のドリルロッドを用い、スパ

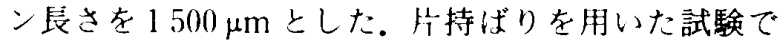
は，欮 2 に示す $L$ が $350 \mu \mathrm{m}$ あるいは $750 \mu \mathrm{m}$ の位置 に荷重を幊荷した。試験は奏験空空中で行ったが,一 部の)試験ではイオン交換水（此抵抗>1 $\mathrm{M} \Omega \cdot \mathrm{cm}$ )で湿 らせた脱脂綿を用いて図 2 の斜線部を稪った，水環境 条件ドで坡労試験を行った。なお，破断後抢よび中断

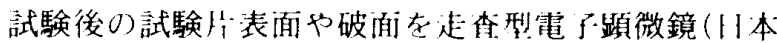

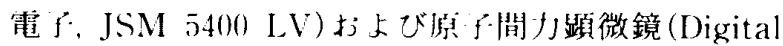
Instruments 社: Nanoscope III)で詳䋱に観祭した。

\section{3. 実験結果および考察}

$3 \cdot 1$ 片持ばり静的曲げ試験＼cjkstart应 4 に幅 $95 \mu \mathrm{m}$ ) 武験けをを用いて静的曲げ荷重を負荷したとき0荷重 変储朋線を，また，荷重負荷㨁前と $70 \mathrm{mN}$ のきの 試験けの変形と破断後の試験片の様子をマイクロスコ 一ブ在朋いて観察した結果を四 5 に示す。荷重 変估朋 線は，破断荷重が $100 \mathrm{mN}$ にも満たない小さな俌であ るにもかかおらず，試験荷重範閒内で直線であり，静 的曲げ試験が精度よく実施さ扎たことままた、シリコ ン単結昆は最終破壊に至るまで弾性変形を星し、脆性 的に破壊が生じたことが明らかである。先に報告した

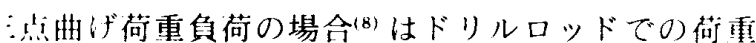

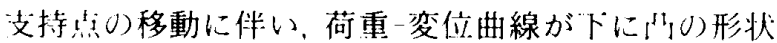
在们し，荷重支持点移動を補作する必要があり，声た

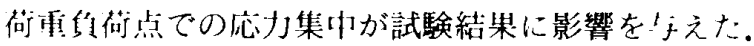
しかしながら，片持ばりではそのような影響は生じず、 本研究で扱う微小機械要素に対する評価試験法として

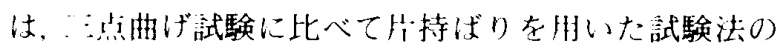
ほうが俊机ている。

[汹6(a)，(b)に，曲げ試験より求めた引張破壊強

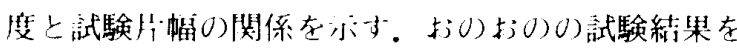

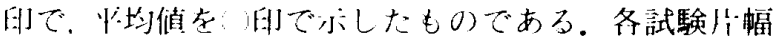

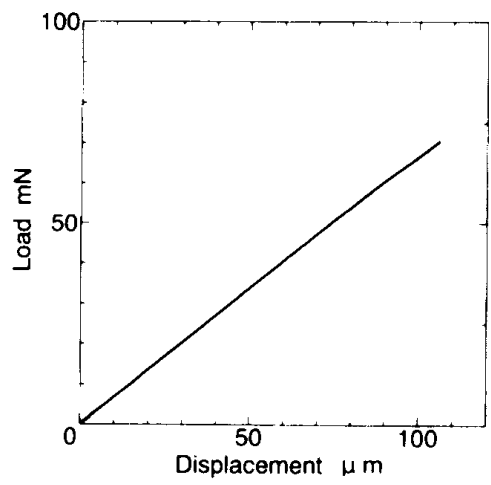

Fig. 4 Load displacement curve of a microcantilever (Width : $95 \mu \mathrm{m}$ )
における試験片本数は1015 本である。片持ばり試験 片は試験け付け根付近で板厚が厚くなっており，試験 片付け根より $100150 \mu \mathrm{m}$ ほど離れた付近で破断した (図 2).したがって，破断強度を求める際には，スパン 長さとして荷重点から破断位置までの長さを採用し た。図 6 より最小破壊強度は幅 $45 \mu \mathrm{m}$ の試験片以外は 2 GPa 程度とほぼ-定檤を保つが，強度の最大値ある いは性值は試験/幅が小きくなるにしたがい大きく なり，強度に刘する寸法効果が現れている。シリコン

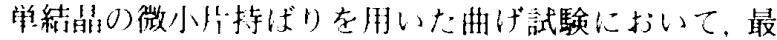

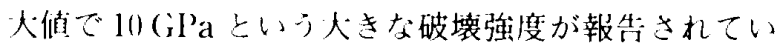

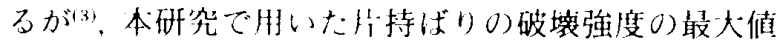
は7.7GPaであり，その做に近い大きな值となった。 なお，先に述へたように，試験片は付け根より100 $150 \mu \mathrm{m}$ 攺ど離机大付近で破断したが、このとき破境

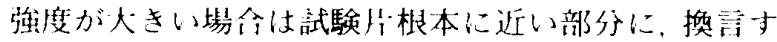

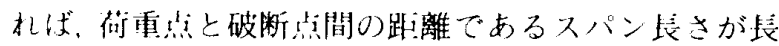
い部分に，また強度が小さい場合はスパン烄さが去く

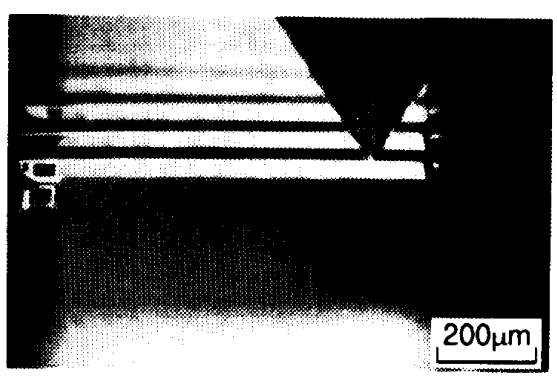

(a) Just before loading

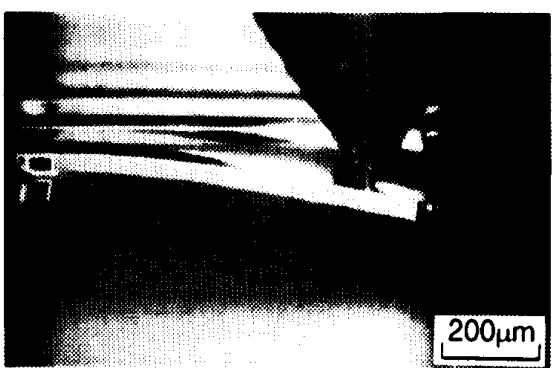

(b) Load: $70 \mathrm{mN}$

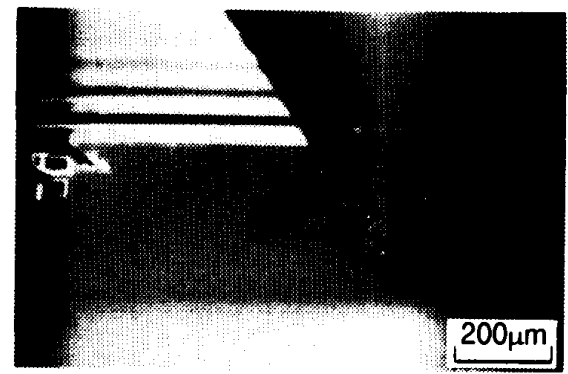

(c) Just after breakage

Fig. 5 I Deformation of microcantilever specimen 
分布する傾响となった。これは、シリコン単結晶は脆 性材料であり表面久楩に敏感であるため(9)，大きな欠 陥がなく強度が大きい場命は，応力が大きくなる試験 片根本付近で破壊するのに対して，比較的大きな欠陷 をも一場合はその久陷部分から破壞に至り，スパン長 さが泣く分布する結果となったものである。

なお，異方性エッチング三点曲げ試験片では，試験 片幅が 65-200 $\mu \mathrm{m}$ の範囲で最大破断強度が約 $3 \mathrm{GPa}$, 平均強度が約 $2 \mathrm{GPa}$ と, 破断強度に試験片幅の依存性

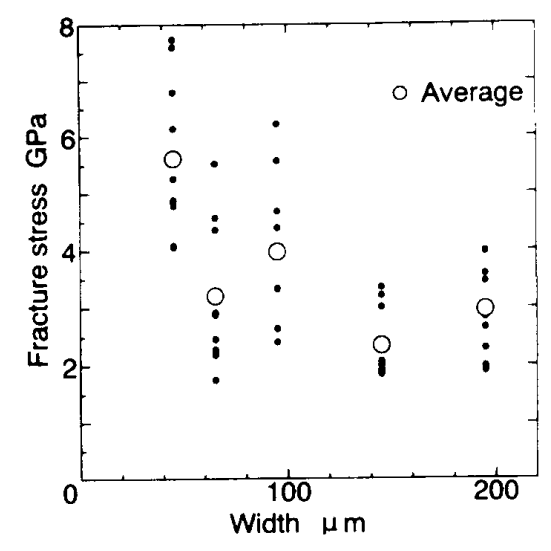

(a) $L=350 \mu \mathrm{m}$

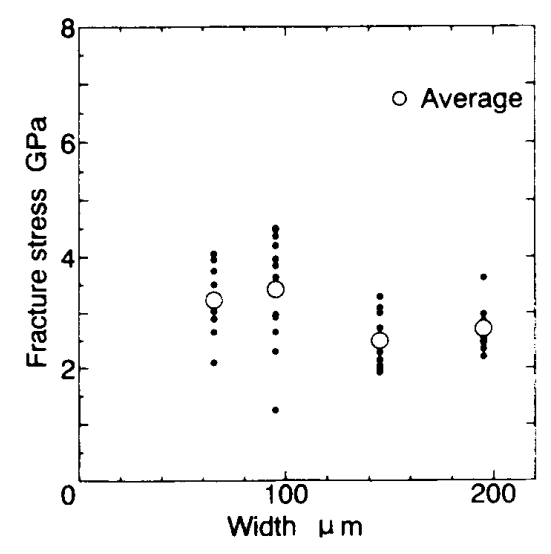

(b) $\quad I=750 \mu \mathrm{m}$

Fig. 6 Relation between fracture strength and specimen width (microcantilever specimens)

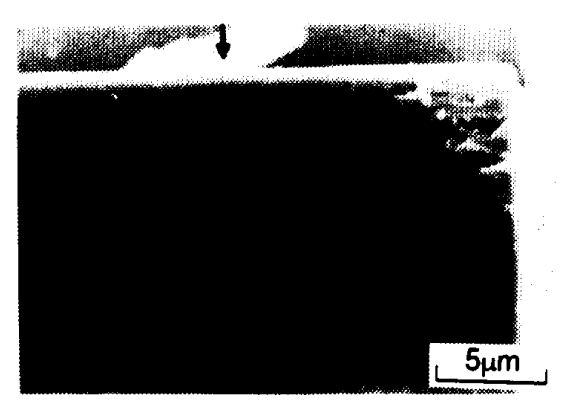

Fig. 7 SEM photograph of fracture surface of a microcantilever beam specimen subjected to monotonic loading (Specimen width: $45 \mu \mathrm{m}$, Fracture strength : $6.8(\mathrm{GPa})$
が見られず，また，強度自身も片持ばり試験片に比べ て小さくなっだ(8)が,これは，荷重点压子值トにおけ る念力集中に加え，エッチング面の表面粗さが片持ば り試験片に比べて大きかったためである。

四てに片持ばりの静的破壤試験で得た破面のSEM 写真を示す。図に示すようにラジアルマーキングをも とに起点(図中に矢印で示す)をたどることは可能であ るが, SEMの分解能では起点が何であるかを確認す ることはできなかった。起点を半無限板中のき裂とし， シリコン単結晶の破壊勒性值を $K_{1 C}=0.9$ $\mathrm{MPa} \cdot \mathrm{m}^{1 / 2(5)(6)}$ として， $K_{1}=1.12 \sigma(\pi a)^{1 / 2}$ を用いて久陮 の大きさを求めると数 $\mathrm{nm}$ 程度の大きさとなり， SEM による起点の確諗は困難である。まだ、シリコン 単結晶においては，金属材料や七ラミックス材料と比 較すると破面の粗さが非常に小さいことが特徵( ${ }^{\left({ }^{\prime}\right)(10)}$ である。

\section{$3 \cdot 2$ 疲労破壤特性}

$\mathbf{3 \cdot 2 \cdot 1}$ 空中疲労特性. 図 8,9 に, 㭅点曲げおよ び片持ばり試験片を用いた被労試験ゆの荷重負荷に伴

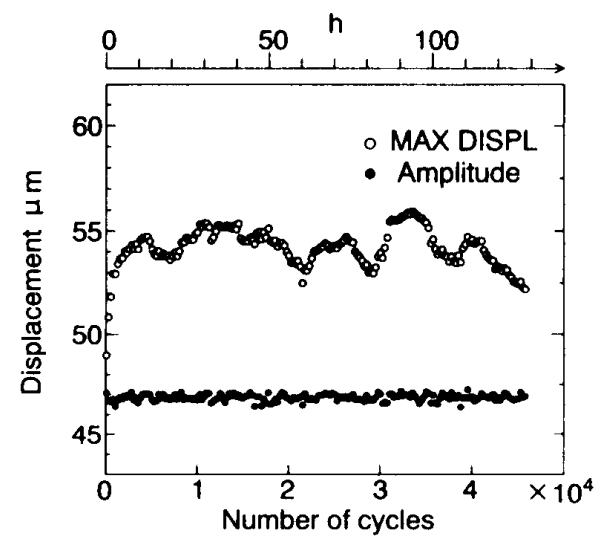

Fig. 8 Changes in displacement during fatigue tests (Three point bending specimen)

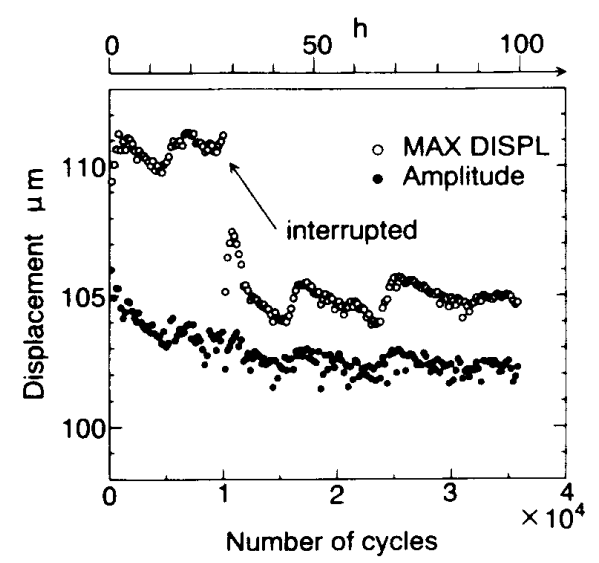

Fig. 9 Changes in displacement during fatigue tests (Microcantilever beam specimen) 
Table 2 Fatigue lives of microcantilever beam specimens conducted in laboratory air (Specimen width: $95 \mu \mathrm{m}$, Maximum load: $75 \mathrm{mN}, I .: 750 \mu \mathrm{m}, R=0.01$ )

\begin{tabular}{|c|c|c|c|c|c|c|c|}
\hline Sample No. & 1 & 2 & 3 & 4 & 5 & 6 & 7 \\
\hline$N$ & $3.6 \times 10^{4}$ & 17 & $<1$ & $4.4 \times 10^{4}$ & $>5.0 \times 10^{4}$ & $<1$ & $>5.0 \times 10^{4}$ \\
\hline
\end{tabular}

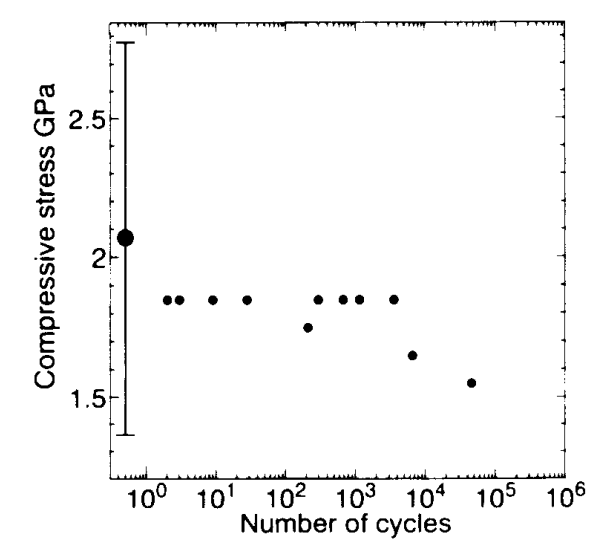

Fig. 10 is curves of three point bending specimens conducted in laboratory air

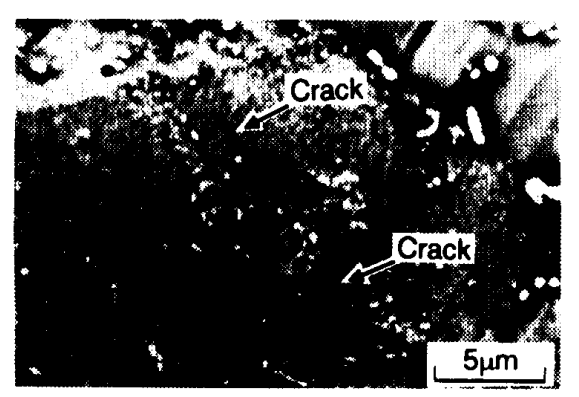

Fig. 11 Fatigue crack, initiated at the loading point (Laboratory air)

う荷重点変位の時間変化を示す。三点曲げ試験片の場

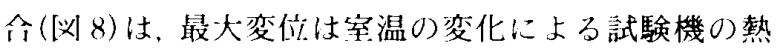
膨張のため約 $3 \mu \mathrm{m}$ の範曲で変動しているのに対して，

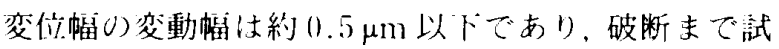
験片コンブライナンス0储は一走储を休一たまま最終 破壊に允ったことがおかる。

・j，片持ばり試験片の場命(㲸9)は，矢印で小方 時点で武験を断して，さらに破壊に等るまで荷重を

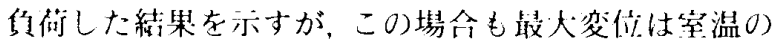
変化に上る試験機の熱膨張のた橍期的に変化した。 それに対して，変位幅に対する空温の変化の影翼は最 大変位に比較与ると小さいが、2 2 m 程度つばら一き

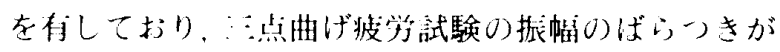
$0.5 \mu \mathrm{m}$ であったことと比較するとばらつつが大きく なる結果となった。また，最大变估に一いても，繰返し に伴い減少寸る傾向にあるが，原灲什不明である。

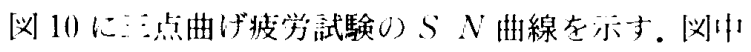

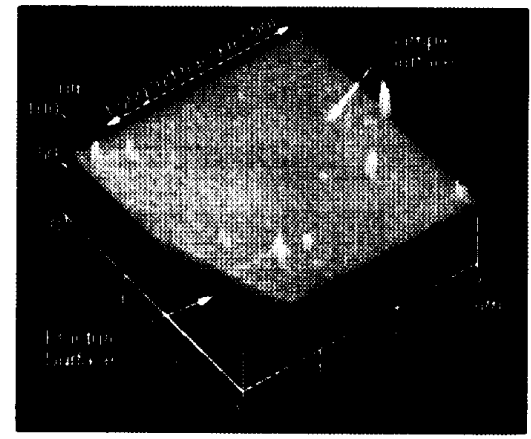

(a) Low magnification AFM image

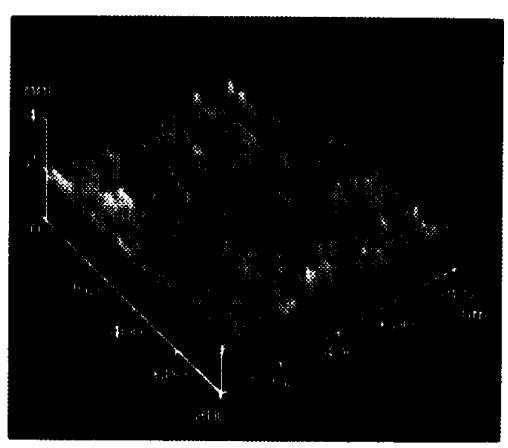

(b) High magnification AFM image of Fig. 12(a)

Fig. 12 specimen surface fatigued in laboratory air, imaged with AFM. (Microcantilever specimen)

左端の $n=0.5$ はに:点曲げ強度の均值を○印で,

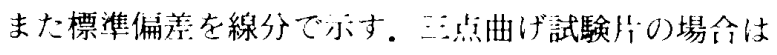

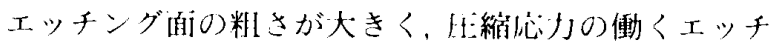

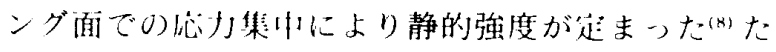

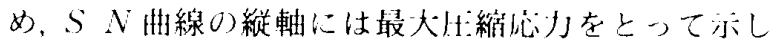

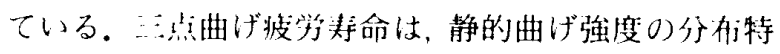
性と刘心して，运くばらつく結果となった。試験を中 断して荷重划子近傍をSEMを啝いて観察した一例を 炏11に示すが，荷重点より長さ数 $\mu \mathrm{m} 0$ の裂が観祭

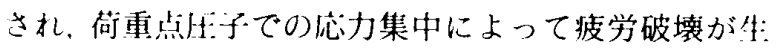
じたことがわかる。

次に，荷重点日㐿での忍力集中が無視できるけ持げ り試験片の轪労試験結果を表 2 に示寸。試験は， $L=$ $750 \mu \mathrm{m}$ の位置に最大荷重 $75 \mathrm{mN}$ を負荷した。この場 命， $L=100 \mu \mathrm{m}$ での最大忍力は $3.4 \mathrm{GPa}$ となる。波爫 試験は，表中10) Sample Numberの順に䘕ったが，試 験の覑忬に無関係に，披学寿命が㕕く分布する結果と

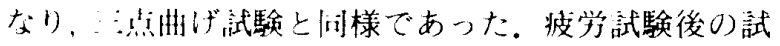


Table 3 Fatigue lives of microcantilever beam specimens conducted in water (Specimen width : $95 \mu \mathrm{m}$, Maximum load: $75 \mathrm{mN}, I=750 \mu \mathrm{m}, R--0.01$ )

\begin{tabular}{|ccc|c|c|ccc}
\hline Sample No. & 1 & 2 & 3 & 4 & 5 & 6 & 7 \\
\hline$N_{1}$ & $>5.0 \times 10^{4}>5.0 \times 10^{4}$ & $4.9 \times 10^{4}$ & $4.5 \times 10^{4}$ & $9.2 \times 10^{2}$ & $7.5 \times 10^{3}$ & $6.8 \times 10^{2}$ \\
\hline
\end{tabular}

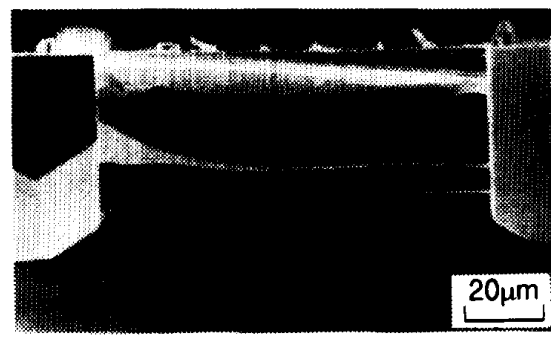

(a) Laboratory air

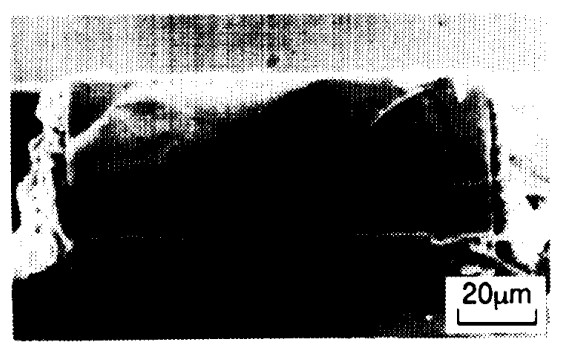

(b) Water

Fig. 13 SEM photographs of fatigue fracture surface of microcantilever beam specimens

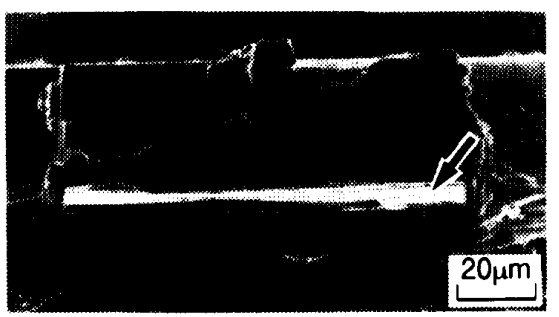

(a) Front view

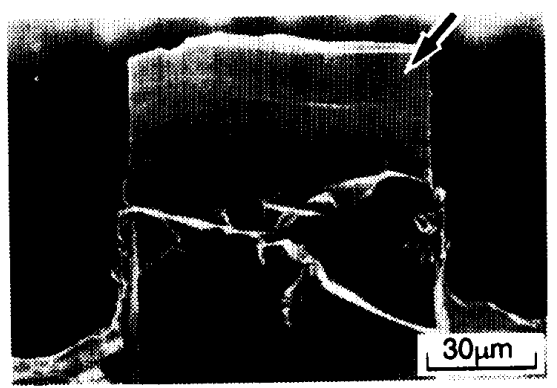

(b) Top view

Fig. 14 SEM photograph of microcantilever beam specimen fatigued in water (Longitudinal crack is shown by arrow)

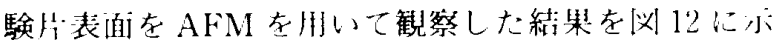

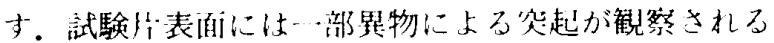

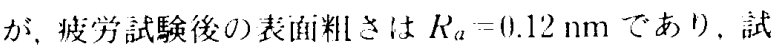

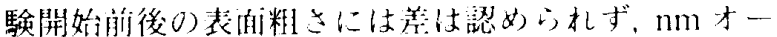

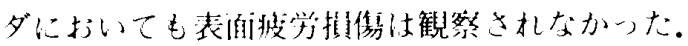

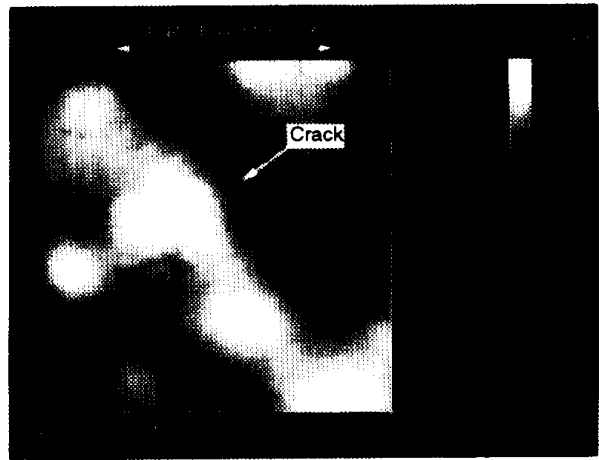

(a) Low magnification AFM image

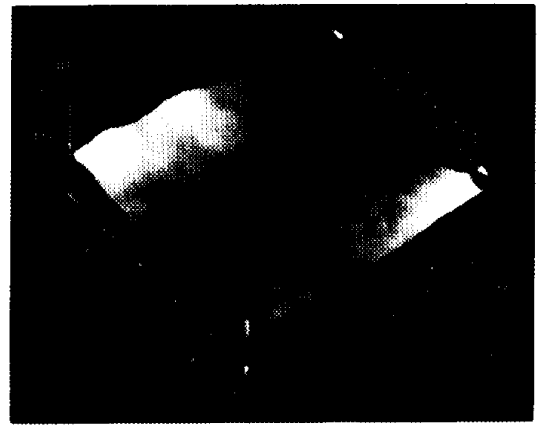

(b) High magnification $\mathrm{AFM}$ image of Fig 15 (a)

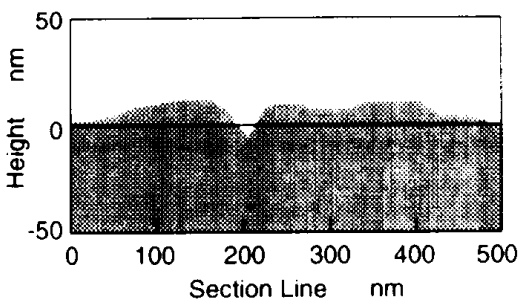

(c) Cross section of a crack observed in Fig. 15(b)

Fig. 15 Specimen surface fatigued in water imaged with AFM

(Microcantilever beam specimen, $n 5 \times 10^{4}$ )

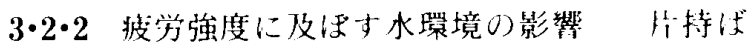

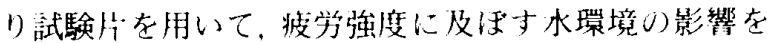

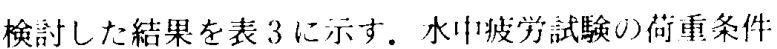
は空中披労試験と间一である。試験は，表中10) Sample

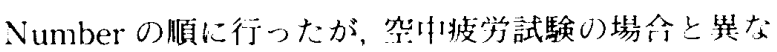

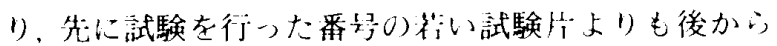

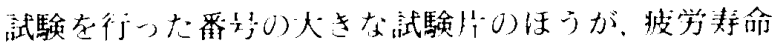

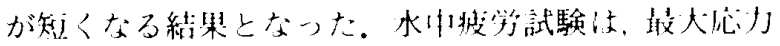

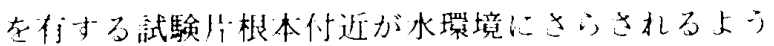

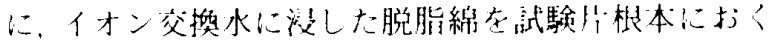


ことにより奏現したが、この場会, 披労試験を行って

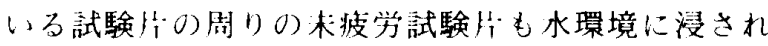
る。したがーてて、後に試験を行ったた試験片ほど長期間 水中に没清される絹果となり，披学寿命が Sample Numberが大い隹ど低卜゙る傾问となったもので ある

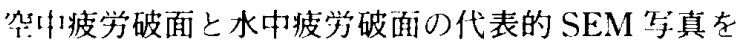
汹 13 に示す。これより，水中疲労破面のほうが空中被 等破面に比べて，破面のマクロな帆らが大きいことが わかる。これは，空中疲労では，静的曲げ試験と同様に 巣一・裂が発生・進展して最終破壊がもたらされたの に対して，水中疲労では，複数のき裂が発生・進展した こと在示唆している。また，水中疲労では，図 14 に示 寸占に試験片長手方向にき裂が進展する場合もあっ た。この上うな鿏手加间き裂は空如披労ではまったく 観察されず，水環境独特のも0上考えられるが、こ0 き裂発生・進展機構については，さらなる研究が必要 である。

$5 \times 10^{4}$ サイクル荷重を負荷した水中疲労試験片の 根本付近の AFM 像を図15に六す。図15(a) は AFM像を濃淡酒像として表したものであり，各梷で の明るさがその点での高低を表しており，明るい部分 が亮い部尔に，暗い部予が低い部行に対忍する。史た，

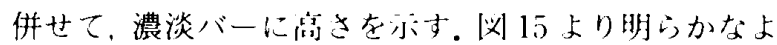

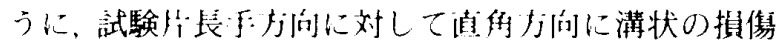

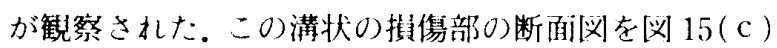
に示すように，摃鹤深さは約 $20 \mathrm{~nm}$ 程度であり，水壊 境と披学荷重の相乗效果により生じたものであり，水 中においては、このようなき裂が発生・進展して最終 破境に等一たものと考えられる。従来，シリコン単結

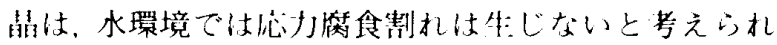
ていた(11)が，動的伈力条件に扔いては，水環境との相 乗効果により $\mathrm{nm}$ オーダでき裂発生が促進される場命 があるようであり，注意を要する。

\section{4. 結喜}

電磁力积荷力式により微小荷重を精密に傊荷するこ とのできる微小材料機械的特性棓価試験機を用いて， 翼方性エッチングにより作成したシリコン単結晶マイ クロエレメント片持ばり試験片と三点曲げ試験片を用 いて，静的曲げ試験・疲学試験，さらに波労強度に及ぼ す水環境の影響を検郭した。得られた結果をまとめる と以ドのようである。
（1） :点曲げ試験片の破壊強度は，試験片一表面粗 さが大きく，しかも荷重負荷点值ドの仙力集中により 破壊挙動が支配されるため，強度特性には試験片サイ ズの影響は見られなか一た。しかし，表面粗さが小き

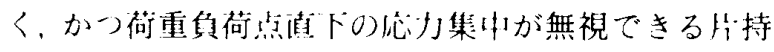
ばり試験片では、試験片サイズが小さくなるほど最大 破壊強度が大きくなるとともに，強度自身も三点曲げ 試験㸝に比べて大きくなった。

（2）シリコン単結晶マイクロエレメントの試験方 法としては，片持ばり試験片を用いるほうが二点曲げ 試験片より優れている。

(3) 三点曲げ被学試験においては、披労が観祭さ れ，倨重魵荷点よりき裂が発生・進展していることが 確認された。

（4）荷重点鱼荷淔下の応力集中の無視できる片持 ばり披労試験においても，空中・水中いずれの環境に 揖いても, 疲労挙動が観察された。

（5）水中疲労では，水環境中にさらされている時 間が衰くなるほど、波労寿命が短くなる傾向が見ら机 た.

（6）空中被労に打いては，AFM を用いた nm才 ーダの観祭に打いても表涌披学損㑺は観察されなか力 たが，水中披労に扔いては，動的忍力と水環境の柏乗 効果により生じた $\mathrm{nm}$ オーダの微小き裂が観祭され た。

\section{文献}

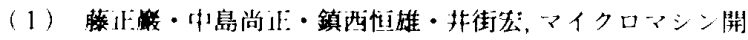
発ノートブック，(1991)，秀潤社.

(2) 滕II機新, 97905 (1994), 311314

(3) Johansson, S. and Schweitz, J. A.. J. Appl. Phys., 6310 (1988), $47994 \times(1) 3$.

(4) Ericson, F., Johansson, S. and Schweitz, J. A., Mater. Sci. Eng.. A 105/106 (1988), $131 \cdot 141$.

(5) Ericson, F, and Schweitz. J. A., J. Appl. Phw.. 6811 (1990), 5840 5844 .

(6) Johansson, S., Ericson, F. and Schweitz, J. A., J. Appl. Phys., 651 (1989), 122-128.

( 7 ) Ogawa, II., Ishikawa, Y. and Kitahara, T., Proc. 2nd Japan France Congress on Mechatronics. (1994), 465) 468 .

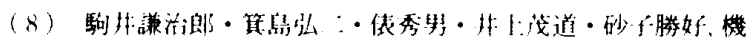
論, 60569, A (1994), 52 58.

(9) Suresh, S., . Hard Mater., 212 (1991), 2954

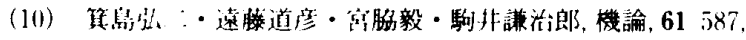
A (1995) . 1587 1594 .

(11) Wong. B. and Holbrook, R. J., J. Electrochem. Sor., 134 $9(19 \times 7), 22542256$ 